\title{
INTERACTIONS BETWEEN DIAZOTROPHIC BACTERIA AND MYCORRHIZAL FUNGUS IN MAIZE GENOTYPES
}

\author{
Marina Yumi Horta Miyauchi ${ }^{1,3}$; Dáfila Santos Lima ${ }^{2,3}$; Marco Antonio Nogueira ${ }^{3 *}$; Gisele \\ Milani Lovato ${ }^{1,3}$; Letícia Sayuri Murate ${ }^{1,3}$; Márcio Ferreira Cruz ${ }^{3}$; Josué Maldonado Ferreira ${ }^{4}$; \\ Waldemar Zangaro ${ }^{5}$; Galdino Andrade ${ }^{3}$ \\ ${ }^{1}$ UEL/CCB - Programa de Pós-Graduação em Microbiologia. \\ ${ }_{3}^{2}$ UEL/CCA - Programa de Pós-Graduação em Agronomia Solos. \\ ${ }^{3}$ UEL/CCB - Depto. de Microbiologia - Lab. de Ecologia Microbiana, C.P. 6001 - 86051-990 - Londrina, PR - \\ Brasil. \\ ${ }_{5}^{4} U E L / C C B$ - Depto. de Biologia Geral - Lab. de Melhoramento Genético. \\ ${ }^{5} U E L / C C B$ - Depto. de Biologia Animal e Vegetal. \\ *Corresponding author <nogueira@uel.br>
}

ABSTRACT: Some diazotrophic bacteria can fix nitrogen biologically in gramineous host plants. Generally, gramineous plants are also associated with mycorrhizal fungi, that can improve mainly plant $\mathrm{P}$ uptake. Among the factors affecting plant-microbe interactions, the plant genotype plays an important role. This study evaluates the effect of diazotrophic bacteria and an arbuscular mycorrhizal fungus (AMF), on five genotypes of maize (Zea mays L.), in relation to plant biomass, shoot $\mathrm{N}$ and $\mathrm{P}$ concentrations, and fine root morphological traits. The experimental design was entirely randomized in a factorial $5 \times 4 \times 2$ arrangement, i.e., five maize genotypes (hybrids C333B, AS3466, and PREMIUM, and the inbreed lines $\lg 40897-1$ and $\lg 40505-1$ ), three diazotrophic bacteria (Azospirillum lipoferum, $A$. amazonense, and Burkholderia sp.) in addition to a control without bacterial inoculation, co-inoculated or not with the AMF Glomus clarum. The non-mycorrhizal plants inoculated with Azospirillum exhibited the highest $\mathrm{N}$ concentrations. The lines lg40897-1 and lg40505-1 showed higher P concentrations as compared to the hybrids, mainly when colonized by AMF. The higher levels of mycorrhizal colonization (90\%) occurred in the C333B and $\lg 40897-1$ genotypes, which also exhibited a greater root diameter. Mycorrhiza increased shoot and root biomass, besides root traits as total length, specific length, total surface, and incidence of root hairs in all genotypes. In addition, mycorrhiza also stimulated the root colonization by diazotrophic bacteria. The bacteria did not affect root morphological traits and mycorrhizal colonization.

Key words: Azospirillum, biological nitrogen fixation, mycorrhiza, root morphology

\section{INTERAÇÕES ENTRE BACTÉRIAS DIAZOTRÓFICAS E FUNGO MICORRÍZICO EM GENÓTIPOS DE MILHO}

RESUMO: Algumas bactérias diazotróficas podem fixar $\mathrm{N}$ biologicamente em gramíneas, as quais se associam a fungos micorrízicos, o que pode levar a um aumento principalmente da absorção de $\mathrm{P}$. Dentre os fatores que afetam as interações planta-microrganismos, o genótipo da planta tem importante papel. Esse trabalho avalia o efeito de bactérias diazotróficas e de um fungo micorrízico arbuscular (FMA) em cinco genótipos de milho (Zea mays L.), em relação à biomassa das plantas, teores de $\mathrm{N} \mathrm{e}$ $\mathrm{P}$ na parte aérea e parâmetros relacionados à morfologia das raízes finas. O delineamento experimental foi inteiramente casualizado, em arranjo fatorial $5 \times 4 \times 2$, sendo cinco genótipos de milho (híbridos C333B, AS3466, PREMIUM e as linhagens lg40897-1 e lg40505-1), três bactérias diazotróficas (Azospirillum lipoferum, A. amazonense e Burkholderia sp.), mais um controle sem bactéria, coinoculadas ou não com o FMA Glomus clarum. As plantas sem FMA e inoculadas com Azospirillum apresentaram os maiores teores de N. As linhagens $\lg 40897-1$ e $\lg 40505-1$ apresentaram maior concentração de $\mathrm{P}$ em relação aos híbridos, principalmente quando micorrizadas. Os maiores níveis de colonização micorrízica (90\%) ocorreram nos genótipos C333B e lg40897-1 que, por sua vez, apresentaram maior diâmetro de raízes. O FMA aumentou a biomassa da parte aérea e das raízes, comprimento total e específico, superfície total e incidência de pêlos nas raízes em todos os genótipos. O fungo micorrízico também estimulou a colonização das raízes pelas bactérias diazotróficas. Já as bactérias não alteraram as características morfológicas das raízes e nem a colonização micorrízica. Palavras-chave: Azospirillum, fixação biológica do nitrogênio, micorriza, morfologia de raízes finas 


\section{INTRODUCTION}

Some soilborne microorganisms may improve plant growth via hormonal and/or nutritional effects, as do some diazotrophic bacteria (Perin et al., 2003; Raimam et al., 2007) and arbuscular mycorrhizal fungi (AMF). Some species of the genus Azospirillum, besides fixing nitrogen, may also stimulate plant growth by means of phytohormones (Reis-Júnior et al., 2004). Phytohormones also increase some root morphological traits, such as root hair incidence, root length and branching.

The external AMF hyphae extend beyond the limits of the rhizosphere, improving the plant's capacity for mining P from soil (Marschner \& Dell, 1994). Some bacteria may stimulate hyphal branching and consequently the amount of infective mycelium (Barea et al., 2002). In addition, AMF spores may be colonized by other microorganisms, including diazotrophic bacteria (Xavier \& Germida, 2003).

Root morphological traits, such as total root length, total root surface, root diameter and root hair density are related to $\mathrm{P}$ uptake in maize and depend on the plant genotype (Machado et al., 2001). In turn, AMF and diazotrophic bacteria may affect root morphological traits.

In this study we aimed to obtain more detailed information about the interaction between diazotrophic bacteria and AMF on plant growth, root morphological traits, and $\mathrm{N}$ and $\mathrm{P}$ concentrations in five maize genotypes differing in rusticity, under low availability of $\mathrm{N}$ and $\mathrm{P}$. Our hypothesis was that the most rustic genotype(s) have a greater tendency to be colonized by diazotrophic bacteria and AMF and benefit more from the microbial interaction.

\section{MATERIAL AND METHODS}

The experiment was carried out in a greenhouse in Londrina, PR, Brazil, from Oct/2004 to Jan/ 2005. The experimental design was entirely randomized in a $5 \times 4 \times 2$ factorial arrangement, respectively: five maize genotypes (hybrids C333B, considered rustic, AS3466, PREMIUM, and the inbreed lines $\lg 40897-1$ and $\lg 40505-1)$, three diazotrophic bacteria (Azospirillum lipoferum - BR11080, A. amazonense BR11140, and Burkholderia sp.) and a control without bacteria, in combination with or without the inoculation of the AMF Glomus clarum, with five replications. The mycorrhizal inoculum was obtained from a pot culture with Brachiaria decumbens as host plant.

The substrate consisted of a mix of a top-layer $(0-20 \mathrm{~cm})$ sample of an acidic, poor, sandy Oxisol, with washed river sand $(3: 1 \mathrm{v} / \mathrm{v})$. The objective of the sandy substrate was to decrease soil fertility and to allow for an easier extraction of mycorrhizal external mycelium and roots. Plastic pots were filled with two $\mathrm{kg}$ of the substrate and then fumigated with methyl bromide for one week. Pots were then kept in the open air for one week to remove fumigant residues. The chemical characteristics of the substrate were as follows: $\mathrm{pH}\left(0.01 \mathrm{M} \mathrm{CaCl}_{2}\right) 4.5 ; \mathrm{C} 11.04 \mathrm{~g} \mathrm{dm}^{-3} ; \mathrm{P} 2.0$ $\mathrm{mg} \mathrm{dm} ; \mathrm{Al}^{3+} 5.7 \mathrm{mmol} \mathrm{dm}^{-3} ; \mathrm{H}+\mathrm{Al} 53.4 \mathrm{mmol} \mathrm{dm}_{\mathrm{c}}^{-3}$; $\mathrm{Ca}^{2+} 13 \mathrm{mmol} \mathrm{dm}^{-3} ; \mathrm{Mg}^{\mathcal{S}_{+}} 7.8 \mathrm{mmol}_{\mathrm{c}} \mathrm{dm}^{-3} ; \mathrm{K}^{+} 0.5 \mathrm{mmol}$ $\mathrm{dm}^{-3}$; CEC $74.7 \mathrm{mmol}_{\mathrm{c}} \mathrm{dm}^{-3}$ and bases saturation (V) $28 \%$.

Each pot was sown with five maize seeds and simultaneously inoculated with AMF. The mycorrhizal inoculum, consisting of $2 \mathrm{~g}$ of soil from stock cultures, containing spores (about $20 \mathrm{~g}^{-1}$ ), hyphae, and colonized root fragments, was placed into the center of the pots, $3 \mathrm{~cm}$ below the surface. The non-mycorrhizal pots also received $2 \mathrm{~g}$ of the same soil, without AMF propagules. The inoculation with diazotrophic bacteria was carried out $24 \mathrm{~h}$ after sowing. Each bacterial species was grown in nutrient broth for $36 \mathrm{~h}$ at $25.5^{\circ} \mathrm{C}$ on a horizontal shaker at $150 \mathrm{rpm}$. Afterwards, each isolate was spread three times on NFB medium (Döbereiner \& Day, 1976). The growth from the third spreading was suspended in sterile saline $(\mathrm{NaCl} 0.85 \%)$ containing $0.05 \%$ of Tween 80 . The cell suspensions were adjusted spectrophotometrically $(\lambda=650 \mathrm{\eta m})$ to $10^{9} \mathrm{CFU} \mathrm{mL} \mathrm{m}^{-1}$ and $10 \mathrm{~mL}$ were applied onto the substrate of each pot. The non-bacterial control pots received $10 \mathrm{~mL}$ of the same sterile saline. Finally, the pots received a layer $(c a .0 .5 \mathrm{~cm})$ of sterile sand at the surface in order to reduce water evaporation and contamination between treatments. After a 12-day period, plantlets were thinned to one per pot. Three weeks after sowing, all pots received $10 \mathrm{~mL}$ of the Hewitt's nutrient solution without N (Hewitt, 1966), a procedure that was repeated weekly. At the first two weeks, the nutrient solution presented normal $\mathrm{P}$ concentration, which was reduced to $1 / 5$ for the following applications.

Plants were harvested 75 days after sowing. Shoots and roots were washed in distilled water; fresh roots were weighed and samples taken for analyses. The remaining roots and shoots were oven-dried at $60^{\circ} \mathrm{C}$ for $72 \mathrm{~h}$, and weighed. The shoot was then ground and acid-digested for $\mathrm{N}$ and $\mathrm{P}$ analyses (Sarruge \& Haag, 1974). $\mathrm{N}$ was determined by semi-micro Kjeldahl distillation (Bremner \& Mulvaney, 1982) and $\mathrm{P}$ was determined colorimetrically by the ascorbic acid method (Murphy \& Riley, 1962).

Fresh root samples were evaluated for mycorrhizal colonization after clearing with $10 \% \mathrm{KOH}$ and coloration with trypan blue (Phillips \& Hayman, 1970), 
at $40 \times$ magnification by the gridline method (Giovannetti \& Mosse, 1980). The root length was evaluated according to Newman (1966) in fresh root samples. The ratio between the root length and the root dry biomass provided the specific root length $\left(\mathrm{m} \mathrm{g}^{-1}\right.$ dry root).

Fresh root samples were stored in FAA solution $(25 \mathrm{~mL} / 500 \mathrm{~mL} / 120 \mathrm{~mL} / 1000 \mathrm{~mL}$, glacial acetic acid, ethanol, formaldehyde and distilled water, respectively) and the root morphological traits were evaluated according to Zangaro et al. (2005). The root diameter was taken under the microscope at $50 \times$ magnification (Manjunath \& Habte, 1991) and the root hair incidence was assessed in 50 root intersections (Siqueira \& Saggin-Júnior, 2001).

For estimation of external hyphae, five grams of wet soil were suspended in acidified glycerol. A sample of the supernatant was vacuum-filtered through a nitrocellulose-squared membrane and stained with trypan blue. The hyphal fragments touching or crossing the lines on the membrane were counted under microscope at $100 \times$ magnification (Andrade et al., 1997) and the total length was estimated (Newman, 1966) considering the dilutions and the initial soil dry mass.

About $0.1 \mathrm{~g}$ of fresh root was immersed in $70 \%$ ethanol, rinsed in sterile distilled water, and ground in sterile saline. The suspension was diluted serially up to $10^{-5}$ and $50 \mathrm{~mL}$ were spread on NFB medium (Döbereiner \& Day, 1976) for counting the bacterial colonies capable of growing on $\mathrm{N}$-free medium. One gram of rhizospheric soil was suspended in sterile saline and processed similarly.

The effects of treatments or their interactions were tested by analysis of variance (F test) and the means compared by Student's $t$ test $(p<0.05)$, using the software SISVAR, version 4.6 (Build 62) (Ferreira, 1999).

\section{RESULTS AND DISCUSSION}

All plants increased their shoot biomass due to mycorrhizal inoculation (Table 1). The improved growth of mycorrhizal plants is generally attributed to a better nutritional status, especially for P (Marschner $\&$ Dell, 1994). A previous report has also emphasized the stimulation of growth of maize plants due to AMF under low P availability (Cardoso-Filho et al., 1999). The genotype AS3466 showed the highest biomass under both mycorrhizal statuses due to its fast initial growth, typical of early materials, while C333B and lg40897-1 showed the lowest biomasses.

The greater growth of AS3466 was also observed in the presence of each bacteria and in the control (Table 1). The other genotypes showed unlike responses, depending on the bacteria, what may be attributed to the specificity between the plant genotype and the bacterial inoculum (Baldani et al., 1997; Dobbelaere et al., 2003; Perin et al., 2003; Raimam et al., 2007). Positive response of the hybrid AS3466 to Burkholderia sp. may be due to hormonal effects (Reis-Júnior et al., 2004), since this combination resulted in lower $\mathrm{N}$ concentrations in plant tissues, probably due to the dilution effect (Table 2).

Considering the interaction between bacteria and AMF, both Azospirillum isolates increased N concentration in maize plants in the non-mycorrhizal condition (Table 2). There was no effect of bacteria on $\mathrm{N}$ concentration in mycorrhizal plants. In addition, mycorrhiza caused a dilution effect of $\mathrm{N}$ concentration in plants due to enhanced growth. However, if one considers the total $\mathrm{N}$ accumulation in the shoots, mycorrhizal plants had higher $\mathrm{N}$ contents (data not shown).

The interaction between maize genotypes and bacteria showed that the three bacteria increased $\mathrm{N}$ concentrations only in C333B (Table 2). Considering

Table 1 - Shoot dry biomass of maize plants in the interaction between genotypes and arbuscular mycorrhizal fungus (AMF), and in the interaction between genotypes and bacteria.

\begin{tabular}{|c|c|c|c|c|c|c|}
\hline \multirow{2}{*}{ Genotype } & \multicolumn{2}{|c|}{ Fungus } & \multicolumn{4}{|c|}{ Bacteria } \\
\hline & $+\mathrm{AMF}$ & $-\mathrm{AMF}$ & Control & A. lipoferum & A. amazonense & Burkholderia sp. \\
\hline C333B & $4.86 \mathrm{cA}$ & $0.59 \mathrm{cB}$ & $2.74 \mathrm{cA}$ & $2.65 \mathrm{cdA}$ & $2.88 \mathrm{bA}$ & $2.62 \mathrm{cA}$ \\
\hline AS3466 & $6.40 \mathrm{aA}$ & $1.74 \mathrm{aB}$ & $3.93 \mathrm{aB}$ & $4.05 \mathrm{aB}$ & $3.66 \mathrm{aB}$ & $4.65 \mathrm{aA}$ \\
\hline PREMIUM & $5.77 \mathrm{bA}$ & $1.11 \mathrm{bB}$ & $3.42 \mathrm{bA}$ & $3.38 \mathrm{bA}$ & $3.45 \mathrm{aA}$ & $3.52 \mathrm{bA}$ \\
\hline $\lg 40897-1$ & $4.67 \mathrm{cA}$ & $0.60 \mathrm{cB}$ & $2.52 \mathrm{cA}$ & $2.48 \mathrm{dA}$ & $2.80 \mathrm{bA}$ & $2.75 \mathrm{cA}$ \\
\hline $\lg 40505-1$ & $5.46 \mathrm{bA}$ & $0.68 \mathrm{cB}$ & $3.37 \mathrm{bA}$ & $3.10 \mathrm{bcAB}$ & $2.87 \mathrm{bB}$ & $2.94 \mathrm{cAB}$ \\
\hline$S E$ & \multicolumn{2}{|c|}{0.11} & \multicolumn{4}{|c|}{0.16} \\
\hline
\end{tabular}

Means followed by the same letter, small in columns and capital in lines, do not differ (Student's $t$ test, $p<0.05$ ). In the interaction Fungus $\times$ Genotypes, $\mathrm{n}=20$; Bacteria $\times$ Genotypes, $\mathrm{n}=10$. $S E=$ Standard error. 
Table 2 - Nitrogen concentration in the shoot of maize plants, considering the interaction between diazotrophic bacteria and the arbuscular mycorrhizal fungus (AMF), and the interaction between diazotrophic bacteria and maize genotypes.

\begin{tabular}{|c|c|c|c|c|c|c|c|}
\hline \multirow{2}{*}{ Bacteria } & \multicolumn{2}{|c|}{ Fungus } & \multicolumn{5}{|c|}{ Genotypes } \\
\hline & $+\mathrm{AMF}$ & -AMF & C333B & AS3466 & PREMIUM & $\lg 40897-1$ & $\lg 40505-1$ \\
\hline \multicolumn{8}{|c|}{ - } \\
\hline Control & $6.2 \mathrm{aB}$ & $15.1 \mathrm{bA}$ & $7.8 \mathrm{bB}$ & $12.5 \mathrm{aA}$ & $10.2 \mathrm{aAB}$ & $8.6 \mathrm{aAB}$ & $9.8 \mathrm{aAB}$ \\
\hline A. lipoferum & $7.6 \mathrm{aB}$ & $20.0 \mathrm{aA}$ & $16.0 \mathrm{aA}$ & $11.7 \mathrm{abB}$ & $10.5 \mathrm{aB}$ & $12.0 \mathrm{aAB}$ & $11.0 \mathrm{aB}$ \\
\hline A. amazonense & $7.3 \mathrm{aB}$ & $20.3 \mathrm{aA}$ & $16.1 \mathrm{aA}$ & $10.1 \mathrm{abB}$ & $9.7 \mathrm{aB}$ & $11.3 \mathrm{aB}$ & $11.2 \mathrm{aB}$ \\
\hline Burkholderia sp. & $7.5 \mathrm{aB}$ & $17.8 \mathrm{abA}$ & $15.1 \mathrm{aA}$ & $8.1 \mathrm{bC}$ & $12.1 \mathrm{aAB}$ & $10.3 \mathrm{aBC}$ & $12.1 \mathrm{aAB}$ \\
\hline$S E$ & \multicolumn{2}{|c|}{0.82} & \multicolumn{5}{|c|}{1.31} \\
\hline
\end{tabular}

Means followed by the same letter, small in columns and capital in lines, do not differ significantly from one another (Student's $t$ test, $p<0.05)$. In the interaction Fungus $\times$ Bacteria, $\mathrm{n}=25$; Genotypes $\times$ Bacteria, $\mathrm{n}=10$. SE $=$ Standard error.

the non-bacterial control among the genotypes, $\mathrm{N}$ concentration was higher in AS3466 than in C333B. On the other hand, AS3466 exhibited the lowest $\mathrm{N}$ concentration when plants were inoculated with Burkholderia sp B6, emphasizing the dilution effect. The effects of diazotrophic bacteria on gramineous plants are variable (Baldani et al., 1997; Perin et al., 2003; Raimam et al., 2007), even among genotypes of the same species. Besides the interaction with the host, the environmental conditions also affect the interaction between plant and bacteria (Dobbelaere et al., 2003).

The mycorrhizal effect on shoot P concentration depended on the plant genotype (Table 3 ). In the mycorrhizal condition, the lines lg40897-1 and lg40505-1 exhibited a higher P concentration, suggesting that they were more effective in $\mathrm{P}$ uptake when colonized by AMF. This trait, in addition to some root morphological traits, may be of relevance when crossing lines with the aim of obtaining hybrids selected for low-P soils (Gahoonia \& Nielsen, 2004).

Despite the lower P concentration in the shoots under mycorrhizal conditions due to a dilution effect in some genotypes, the $\mathrm{P}$ content in all mycorrhizal plants was greater than in the non-mycorrhizal ones (data not shown), suggesting that mycorrhiza increased plant growth mainly due to increases in P uptake. Even under mycorrhizal conditions, plants showed visual symptoms of $\mathrm{P}$ deficiency, such as purple color and senescence of older leaves, and caused a relative increase of the root system in relation to shoots (Tables 1 and 4), suggesting that $P$ deficiency was more limiting to the shoots than to the roots, as stated by Machado et al. (2001), Machado \& Furlani (2004), and may be looked at as a plant strategy trying to scavenge more nutrients in a low fertility condition.

The root morphological traits and external hyphal length (Table 4) were affected in the interaction between AMF and plant genotype, except for root diameter, that was affected only by plant genotype (Fig-
Table 3 - Phosphorus concentration in the shoot of maize plants in the interaction between plant genotypes and arbuscular mycorrhizal fungus (AMF).

\begin{tabular}{lcc}
\hline \multirow{2}{*}{ Genotype } & \multicolumn{2}{c}{ Fungus } \\
\cline { 2 - 3 } & +AMF & -AMF \\
\hline C333B & $0.55 \mathrm{bB}$ & $0.63 \mathrm{abA}$ \\
AS3466 & $0.52 \mathrm{bA}$ & $0.55 \mathrm{cA}$ \\
PREMIUM & $0.46 \mathrm{cB}$ & $0.58 \mathrm{bcA}$ \\
$\lg 40897-1$ & $0.66 \mathrm{aA}$ & $0.64 \mathrm{aA}$ \\
$\lg 40505-1$ & $0.65 \mathrm{aA}$ & $0.59 \mathrm{abcB}$ \\
\hline$S E$ & \multicolumn{3}{c}{0.02} \\
\hline
\end{tabular}

Means followed by the same letter, small in columns and capital in lines, do not differ (Student's $t$ test, $p<0.05$ ). $\mathrm{n}=20 . S E=$ Standard error.

ure 1A). AMF increased the root dry biomass in all genotypes, likewise the shoots. In this case, the hybrids showed the highest root dry biomass, while the inbreed lines showed lower averages, similarly to the total root length. The total root length increase in mycorrhizal plants can also be due to more roots branching (Bressan \& Vasconcellos, 2002). Although it is quite difficult to find out whether larger root sizes are the effect or the cause of higher P concentrations in plants (Gahoonia \& Nielsen, 2004), it can be suggested that higher $\mathrm{P}$ concentration in the inbreed lines, mainly with AMF, is a specific ability of these genotypes, given that they produced less total root biomass and length (Table 4).

Mycorrhiza increased total root surface and the specific root length in all genotypes (Table 4), with the latter result being in contrast to the findings of Raimam et al. (2007), who reported a reduction of the specific root length of mycorrhizal rice under flooding conditions. In native woody species, mycorrhiza also decreased the specific root length and increased the root diameter (Zangaro et al., 2005, 2007). The increase of the specific root length in the present work was 
Table 4 - Root morphological traits of maize plants and external hyphae length in the interaction between maize genotypes and arbuscular mycorrhizal fungus (AMF).

\begin{tabular}{|c|c|c|c|c|c|c|c|}
\hline \multirow{2}{*}{ Variable } & & \multicolumn{6}{|c|}{ Genotype } \\
\hline & & C333B & AS3466 & PREMIUM & $\lg 40897-1$ & $\lg 40505-1$ & $S E$ \\
\hline \multirow[t]{2}{*}{ Root dry biomass $\left(\mathrm{g} \mathrm{pl}^{-1}\right)$} & -AMF & $0.26 \mathrm{aB}$ & $0.91 \mathrm{aB}$ & $0.48 \mathrm{aB}$ & $0.35 \mathrm{aB}$ & $0.83 \mathrm{aB}$ & 0.24 \\
\hline & $+\mathrm{AMF}$ & $5.29 \mathrm{aA}$ & $4.85 \mathrm{aA}$ & $4.43 \mathrm{aA}$ & $3.36 \mathrm{bA}$ & $2.67 \mathrm{bA}$ & \\
\hline \multirow[t]{2}{*}{ Root length $\left(\mathrm{m} \mathrm{pl}^{-1}\right)$} & $-\mathrm{AMF}$ & $90.25 \mathrm{bcB}$ & $275.35 \mathrm{aB}$ & $152.02 \mathrm{bB}$ & $145.53 \mathrm{bB}$ & $82.90 \mathrm{cB}$ & 22.37 \\
\hline & $+\mathrm{AMF}$ & $576.69 \mathrm{aA}$ & $583.76 \mathrm{aA}$ & 586.79 aA & $505.21 \mathrm{bA}$ & $489.06 \mathrm{bA}$ & \\
\hline \multirow[t]{2}{*}{ Specific root length $\left(\mathrm{m} \mathrm{g}^{-1}\right)$} & $-\mathrm{AMF}$ & $57.71 \mathrm{aB}$ & $52.58 \mathrm{aB}$ & $57.73 \mathrm{aB}$ & $63.72 \mathrm{aB}$ & $60.32 \mathrm{aB}$ & 10.15 \\
\hline & $+\mathrm{AMF}$ & $109.25 \mathrm{bA}$ & $102.91 \mathrm{bcA}$ & $93.51 \mathrm{bcA}$ & $150.61 \mathrm{aA}$ & $79.37 \mathrm{cA}$ & \\
\hline \multirow[t]{2}{*}{ Root surface $\left(\mathrm{cm}^{2} \mathrm{pl}^{-1}\right)$} & -AMF & $511.21 \mathrm{bcB}$ & $1355.58 \mathrm{aB}$ & $680.09 \mathrm{bcB}$ & 891.47 bB & $377.51 \mathrm{cB}$ & 140.63 \\
\hline & $+\mathrm{AMF}$ & $2972.23 \mathrm{aA}$ & $2787.08 \mathrm{aA}$ & $2694.15 \mathrm{aA}$ & $3085.64 \mathrm{aA}$ & $2056.84 \mathrm{bA}$ & \\
\hline \multirow[t]{2}{*}{ Root hair incidence (\%) } & -AMF & $81.60 \mathrm{aB}$ & $67.80 \mathrm{bB}$ & $58.10 \mathrm{cB}$ & $47.20 \mathrm{~dB}$ & $77.50 \mathrm{aB}$ & 2.83 \\
\hline & $+\mathrm{AMF}$ & $92.50 \mathrm{abA}$ & $85.80 \mathrm{bcA}$ & $84.70 \mathrm{cA}$ & $83.70 \mathrm{cA}$ & $95.60 \mathrm{aA}$ & \\
\hline \multirow[t]{2}{*}{ Hyphae length $(\mathrm{m} / \mathrm{g})$} & -AMF & $7.87 \mathrm{aB}$ & $16.50 \mathrm{aB}$ & $13.89 \mathrm{aB}$ & $18.77 \mathrm{aB}$ & $7.16 \mathrm{aB}$ & 8.99 \\
\hline & $+\mathrm{AMF}$ & $51.60 \mathrm{aA}$ & $38.15 \mathrm{bA}$ & $46.63 \mathrm{abA}$ & $41.13 \mathrm{abA}$ & $22.67 \mathrm{cA}$ & \\
\hline
\end{tabular}

For each variable, means followed by the same letter, capital in columns and small in lines, do not differ (Student's $t$ test, $p<0.05$ ). $\mathrm{n}=$ 20. $S E=$ Standard error.
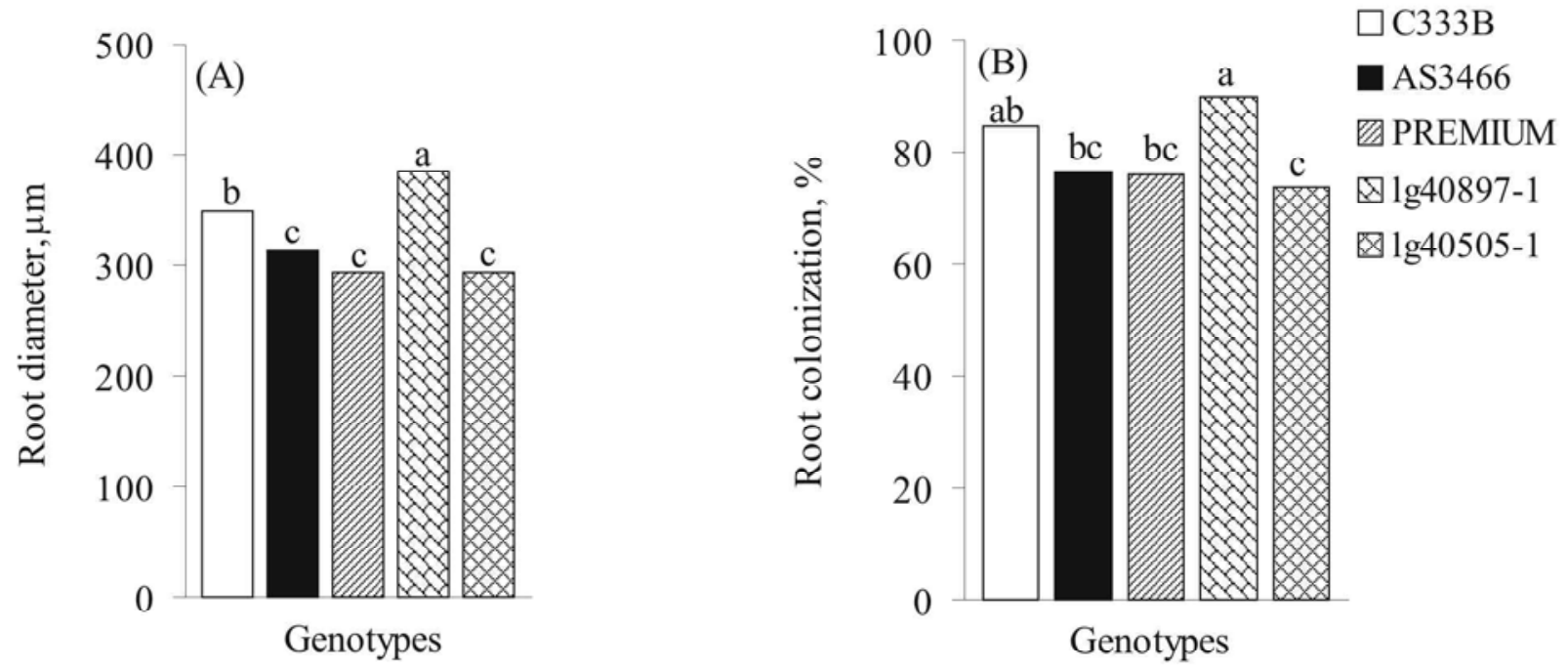

Figure 1 - Single effects of maize genotypes on root diameter (A) and mycorrhizal root colonization (B). Means sharing the same letter do not differ (Student's $t$ test, $p<0.05$ ). For root diameter, $\mathrm{n}=40$, Standard error $(S E)=11.2$; root colonization, $\mathrm{n}=20$, $S E=2.5$.

possibly a consequence of cell enlargement or less lignification of cell walls in mycorrhizal plants. In addition, the increase of total root surface was in part a consequence of the increase in root biomass and length.

In the non-AMF condition, the genotypes C333B and $\lg 40505-1$ showed the greatest root hair incidence (Table 4). C333B presented the second greatest root diameter (Figure 1A), while lg40505-1 had the lowest total root surface (Table 4). The greater incidence of root hairs may be a way to counteract the lower total root surface and/or greater root diameter, thus enhancing some root morphology traits that are responsible for nutrient uptake. Mycorrhiza increased root hair incidence to values above $92 \%$ in the line $\lg 40505-1$ and the hybrid C333B. Conversely, previous reports showed reduction of root hair incidence in mycorrhizal maize (Bressan \& Vasconcellos, 2002) and seedlings of native woody tropical trees (Zangaro et al., 2005, 2007).

The greatest root diameter was found in the genotype $\lg 40897-1$, followed by C333B (Figure 1A). Thicker roots are more lignified, a characteristic that makes it more difficult to take up water and nutrients (Gahoonia \& Nielsen, 2004). However, mycorrhizal colonization may balance such negative aspects (Bressan \& Vasconcellos, 2002). In fact, mycorrhizal root colonization was higher in the genotypes $\lg 40897$ - 



Figure 2 - Mycorrhizal (A) and maize genotypes (B) effects on the occurrence of diazotrophic bacteria in fresh roots of maize. Means sharing the same letter do not differ (Student's $t$ test, $p<0.05$ ). For mycorrhizal effect, $\mathrm{n}=100$, Standard error $(S E)=0.4$; genotypes effect, $\mathrm{n}=40, S E=0.7$.

1 and C333B (Figure 1B). The lowest root colonization of the genotype $\lg 40505-1$ coincided with the lower amount of external hyphal length (Table 4). A mycorrhizal root colonization above $70 \%$ is attributable to the low soil $\mathrm{P}$ availability, indicating that plants rely on mycorrhiza to overcome the soil $\mathrm{P}$ deficit. The levels of mycorrhizal root colonization and corresponding plant growth seems to be variable among the different genotypes. Despite the exciting possibility to manipulate the mycorrhizal symbiosis in breeding programs that arises from these results, studies to explore the plant genotypic variability in relation to mycorrhizal response are relatively rare (Gahoonia \& Nielsen, 2004).

Mycorrhizal colonization increased the number of CFU of diazotrophic bacteria in maize roots at a ratio of about three hundred times (Figure 2A). This effect suggests a beneficial action of AMF in helping the diazotrophic bacteria to penetrate and colonize the plant roots (Raimam et al., 2007). Endophytic diazotrophic bacteria may penetrate the host plant passively by means of small injuries on the root surface like those at the root-emergence sites and at the root cap (Perin et al., 2003). We do not know whether the increase of bacterial colonization in mycorrhizal plants was due to a nutritional effect or if the bacteria entered the plant by means of AMF infecting points in roots. Further studies should be carried out in order to investigate this question. In relation to maize genotypes, the hybrid AS3466 showed 100 times less colonization by diazotrophic bacteria. It is possible that during breeding programs, plant characteristics that could favor the bacterial association have not been selected, resulting in a plant less vulnerable to the colonization by diazotrophic bacteria. The occurrence of diazotrophic bacteria in the rhizospheric soil was not affected by treatments and the average colonization was $7.2 \times 10^{4}$ CFU $\mathrm{g}^{-1}$. Nevertheless, in some situations AMF may stimulate the diazotrophic bacteria in the rhizosphere of rice plants (Raimam et al., 2007).

AMF increased plant biomass and modified some morphological root traits more than did the diazotrophic bacteria. Some root morphological traits were improved by AMF, thus helping the plants to cope with adverse environmental conditions such as low soil fertility. In addition, the AMF stimulated the plant root colonization by diazotrophic bacteria. Nevertheless, the ability of bacteria to colonize the plant roots also depends on the plant genotype. The genotype more demanding for nutrients (AS3466) was less susceptible to colonization by diazotrophic bacteria in roots and was less benefited by mycorrhiza than the genotype C333B, considered more rustic.

\section{ACKNOWLEDGEMENTS}

To Embrapa Agrobiologia for kind supply of the Azospirillum strains BR11080 and BR11140 and to PROPPG/PRODICI-UEL for financial support. M.A. Nogueira is CNPq Scholar.

\section{REFERENCES}

ANDRADE, G.; MIHARA, K.L.; LINDERMAN, R.G.; BETHLENFALVAY, G.J. Bacteria from rhizosphere and hyphosphere soils of different arbuscular-mycorrhizal fungi. Plant and Soil, v.192, p.71-79, 1997.

BALDANI, J.I.; CARUSO, L.; BALDANI, V.L.D.; GOI, S.R.; DÖBEREINER, J. Recent advances in BNF with non-legume plants. Soil Biology \& Biochemistry, v. 29, p.922-928, 1997.

BAREA, J.M.; AZCÓN, R.; AZCÓN-AGUILAR, C. Mycorrhizosphere interactions to improve plant fitness and soil quality. Antonie van Leeuwenhoek, v.81, p.343-351, 2002. 
BREMNER, J.M.; MULVANEY, C.S. Nitrogen-total. In: PAGE, A.L.; MILLER, R.H.; KEENEY, D.R. (Ed.) Methods of soil analysis. Part 2. Chemical and Biological Properties. New York: American Society of Agronomy, 1982. p.595-624.

BRESSAN, W.; VASCONCELLOS, C.A. Alterações morfológicas no sistema radicular do milho induzidas por fungos micorrízicos e fósforo. Pesquisa Agropecuária Brasileira, v.37, p.509$517,2002$.

CARDOSO-FILHO, J.; PACOVSKY, R.S.; CARDOSO, E.J.B.N. Growth and metabolic activity of the extramatricial mycelium of endomycorrhizal maize plants. Revista Brasileira de Ciência do Solo, v.23, p.807-815, 1999.

DOBBELAERE, S.; VANDRLEYDEN, J.; OCON, Y. Plant growthpromoting effects of diazotrophs in the rhizosphere. Critical Reviews in Plant Sciences, v.22, p.107-149, 2003.

DÖBEREINER, J.; DAY, J.M. Associative symbiosis in tropical grasses: characterization of microorganisms and dinitrogen fixing sites. In: INTERNATIONAL SYMPOSIUM ON NITROGEN FIXATION, 1., Pullman, 1976. Proceedings. Pullman: WSU Press, 1976. p.518-538.

FERREIRA, D.F. Programa SISVAR versão 4.6 (Build 62). Lavras: UFLA, 1999. Available at http://www.dex.ufla.br/ $\sim$ danielff/softwares.htm. Accessed 15 Jan. 2007.

GAHOONIA, T.S.; NIELSEN, N.E. Root traits as tools for creating phosphorus efficient crop varieties. Plant and Soil, v.260, p.47-57, 2004.

GIOVANNETTI, M.; MOSSE, B. An evaluation of techniques for measuring vesicular arbuscular mycorrhizal infection in roots. The New Phytologyst, v.84, p.489-500, 1980.

HEWITT, E.J. Sand and water culture methods used in the study of plant nutrition. 2 ed. London: Commonwealth Agricultural Bureau, 1966. 547p.

MACHADO, C.T.T.; FURLANI, A.M.C.; MACHADO, A.T. Índices de eficiência de variedades locais e melhoradas de milho ao fósforo. Bragantia, v.60, p.225-238, 2001.

MACHADO, C.T.T.; FURLANI, A.M.C. Kinetics of phosphorus uptake and root morphology of local and improved varieties of maize. Scientia Agricola, v.61, p.69-76, 2004.

MANJUNATH, A.; HABTE, M. Root morphological characteristics of host species having distinct mycorrhizal dependency. Canadian Journal of Botany, v.69, p. 671-676, 1991.

MARSCHNER, H.; DELL, B. Nutrient uptake in mycorrhizal symbiosis. Plant and Soil, v.159, p.89-102, 1994.

MURPHY, J.; RILEY, J.P. A modified single solution method for the determination of phosphate in natural waters. Analytical Chimica Acta, v.27, p.31-36, 1962.
NEWMAN, J. A method of estimating the total length of root in a sample. Journal of Applied Ecology, v.3, p.139-145, 1966.

PERIN, L.; SILVA, M.F.; FERREIRA, J.S.; CANUTO, E.L.; MEDEIROS, A.F.A.; OLIVARES, F.L.; REIS, V.M. Avaliação da capacidade de estabelecimento endofítico de estirpes de Azospirillum e Herbaspirillum em milho e arroz. Agronomia, v.37, p.47-53, 2003.

PHILLIPS, J.M.; HAYMAN, A.S. Improved procedures for clearing roots and staining parasitic and vesicular-arbuscular mycorrhizal fungi for assessment of infection. Transactions of the British Mycological Society, v.55, p.158-161, 1970.

RAIMAM, M.P.; ALBINO, U.; CRUZ, M.F.; LOVATO, G.M.; SPAGO, F.; FERRACIN, T.P.; LIMA, D.S.; GOULART, T.; BERNARDI, C.M.; MIYAUCHI, M.; NOGUEIRA, M.A.; ANDRADE, G. Interaction among free-living N-fixing bacteria isolated from Drosera villosa var. villosa and AM fungi (Glomus clarum) in rice (Oryza sativa). Applied Soil Ecology, v.35, p.25-34, 2007.

REIS-JÚNIOR, F.B.; SILVA, M.F.; TEIXEIRA, K.R.S.; URQUIAGA, S.; REIS, V.M. Identificação de isolados de Azospirillum amazonense associados a Brachiaria spp., em diferentes épocas e condições de cultivo e produção de fitormônio pela bactéria. Revista Brasileira de Ciência do Solo, v.28, p.103-113, 2004.

SARRUGE, J.R.; HAAG, H.P. Análises químicas em plantas. Piracicaba: USP/ESALQ, 1974. 56p.

SIQUEIRA, J.O.; SAGGIN-JÚNIOR, O.J. Dependency on arbuscular mycorrhizal fungi and responsiveness of some Brazilian native woody species. Mycorrhiza, v.11, p.245-255, 2001.

XAVIER, L.J.C.; GERMIDA, J.J. Bacteria associated with Glomus clarum spores influence mycorrhizal activity. Soil Biology \& Biochemistry, v.35, p.471-478, 2003.

ZANGARO, W.; NISHIDATE, F.R.; CAMARGO, F.R.S; ROMAGNOLI, G.G; VANDRESSEN, J. Relationships among arbuscular mycorrhizas, root morphology and seedling growth of tropical native woody species in southern Brazil. Journal of Tropical Ecology, v.21, p.529-540, 2005.

ZANGARO, W.; NISHIDATE, F.R.; VANDRESEN, J.; ANDRADE, G.; NOGUEIRA, M.A. Root mycorrhizal colonization and plant responsiveness are related to root plasticity, soil fertility and successional status of native woody species in southern Brazil. Journal of Tropical Ecology, v.23, p.53-62, 2007.

Received February 06, 2007

Accepted January 21, 2008 